\title{
Das Ordens de Pagamento
}

\author{
Plínio Palhano \\ (Delegado do Tribunal de Contas no Depar- \\ tamento Federal de Compras)
}

\begin{abstract}
Despesas públicas, no conceito do art. 218 do Regulamento Geral de Contabilidade, são as que podem ser efetuadas pela Administração em decorrência de leis gerais e orgânicas, leis especiais, decretos do Executivo, regulamentos ou outros títulos legais de dívida que determinam fiquem a cargo do Govêrno Federal. Mas, no sentido formal, representam "a aplicação de certa quantia, em dinheiro, por parte da autoridade ou agente público competente, dentro duma autorização legislativa, para execução de fins a cargo do Govêrno:" (Aliomar BALEeiro - Uma Introdução à Ciência das Finanças — vol. I, p. 65).

Contudo, a despesa pública passa por vários estágios. É embrionária na autorização legislativa, que pode ou não ser utilizada pelo Poder Executivo; toma feição no empenho, quando o Estado assume a obrigação, embora preeária, do pagamento; é reconhecida no ato de liquidação, momento em que se verifica o direito adquirido pelos credores do Estado; considera-se legal pelo registro do Tribunal de Contas; e finalmente realiza-se no ato do pagamento. Se o administrador decide empregar o crédito em determinado fim, empenha-o. Prestado o serviço é a despesa liquidada, após o que o pagamento é requisitado à estação pagadora respectiva, mediante ordem de pagamento.
\end{abstract}

A Lei n. ${ }^{\circ} 830$, de 23 de setembro de 1949, que reorganizou o Tribunal de Contas da União, no seu art. 48 enumera os requisitos que as ordens de pagamento devem satisfazer para serem cumpridas:

- ser expedidas por autoridades competentes e dirigidas à estação que houver de cumprí-las, com indicação, por extenso, do nome do credor e da importância do pagamento. Nas ordens coletivas se deverá indicar o número de credores a serem pagos, nomeados em relação, e, bem assim, a importância total dos pagamentos;

- haver sido a despesa imputada ao título orçamentário devido, ou computada em crédito adicional, prèviamente registado, e deduzida dos saldos correspondentes, no ato do empenho;

- haver sido a despesa processada à vista de documentos que a comprovem, respeitado o processo estabelecido por lei; 

derem; e

- guardar conformidade com as cláusulas dos contratos, de que depen-

- ser registradas pelo Tribunal de Contas, ou por suas Delegações.

\section{II}

Ordem de pagamento é o mandado da autoridade administrativa para que se proceda ao pagamento da despesa. Deve ser expedida por escrito, e pelo órgão competente. É, em alguns casos, um simples pague-se. Apôsto o paǵue-se, ou assinada a ordem de pagamento sob qualquer outra fórmula, está a dívida virtualmente reconhecida e esta, além do mandado expresso, é uma das características da ordem de pagamento.

Antes do registro das despesas as ordens de pagamento são submetidas, pelo Corpo Instrutivo do Tribunal de Contas, a exame rigoroso, destinado a apurar se satisfazem a todos os requisitos acima prescritos, assim como às exigências esparsas no Código de Contabilidade, no Regulamento Geral de Contabilidade Pública e nas diversas leis complementares. Entretanto, embora registrada a despesa pelo Tribunal de Contas, subsiste inteira a responsabilidade dos Ministros e Chefes de repartições, quanto à regularidade e conveniência do gasto que empenharam e do respectivo processo de liquidação (Cód., art. 66), tanto que é lícito aos Ministros sustarem o pagamento da despesa registrada, sem que assista qualquer direito de reclamação fundada no ato do Tribunal (art. cit., $\S 10^{\circ}$ ).

O registro também não isenta os agentes pagadores de, por sua vez, efetuarem o mesmo acurado exame, antes de cumprirem as ordens de pagamento. Os órgãos das estações pagadoras incumbidos do cumprimento das ordens emanadas dos diversos setores administrativos, hão de examiná-las antes de realizarem o pagamento, certificando-se prèviamente de que elas atendem a todos os requisitos da lei.

O Regulamento Geral de Contabilidade é explícito quanto aos agentes que devem, no ato de pagar, fazer a última análise do mandado de pagamento, sob pena de serem compelidos a indenizar os cofres públicos das quantias irregularmente pagas (art. 535). São os tesoureiros, pagadores, exatores, etc.. O parágrafo $2 .^{\circ}$ do art. 279 é, aliás, rigorosíssimo: "Verificada a nulidade do pagamento por falta de idoneidade, ou inobservância da formalidades regulamentares, os pagadores deverão entrar, dentro de oito dias, com a importância indevidamente paga, sob pena de suspensão e mais medidas acauteladores dos direitos da Fazenda Nacional". E obrigado, pois, o pagador a verificar a exação da ordem e, no caso de encontrar quaisquer falhas, deve sobrestar o pagamento, dando imediatamente ciência da ocorrência ao seu chefe imediato, a fim de que êste providencie no sentido de ser o êrro sanado (Reg., art. 536).

\section{III}

A ordem de pagamento há de ser expedida por autoridade competente, isto é, aquela que é por lei ou delegação disto incumbida, tendo em vista que competência é o grau de atribuição de cada funcionário ou órgão. "A compe- 
tência decorre da lei, do poder conferido à autoridade administrativa, explìcitamente ou como decorrência da natureza das funções, isto é, como implìcitamente contida nas atribuições gerais e na organização do serviço." Temístocles Cavalcanti - Tratado de Direito Administrativo (vol. V, pág. 292). Pode ser exclusiva ou delegável. No caso das ordenações de pagamento a competência é delegável, porque está situada entre aquelas competências especiais, para que a lei prevê cedência.

São competentes para expedir ordens de pagamento, originalmente, os ministros ou dirigentes de órgãos diretamente subordinados à Presidência da República. Mas, devidamente autorizados, passam a gozar dessa competência ordenadores secundários. Os chefes de repartições ou os servidores a que foram distribuídos créditos ou feitos adiantamentos desfrutam, da mesma forma, da competência de expedí-las.

A delegação de competência pode vir consignada expressamente nas leis orgânicas ou nos regimentos das diversas repartições. Do contrário, constará de ato expresso do primeiro ordenador, ato que será submetido ao conhecimento do Tribunal de Contas ou de suas Delegações. Tal ato conterá o cargo ou o nome do servidor delegado, assim como o limite máximo dentro do qual poderá exercer o mandato (arts. 263 e 264 do R.G.C.P.). E esta uma delegação precária e restrita, que pode cessar a qualquer momento e jamais seexercitará além das limitações estipuladas no ato de delegação.

\section{IV}

As ordens de pagamento devem ser dirigidas à estação que houver decumprí-las, ou seja, àquela para que o crédito foi distribuído. Não poderá uma estação pagadora efetuar pagamento à conta de crédito afeto a outra. Assim, se the fôr dirigida uma ordem de pagamento que não the incumba, tal mandado não deve ser aceito porque não poderá ser cumprido. São estações pagadoras, no Distrito Federal, o Tesouro Nacional, e, nos Estados, as Delegacias Fiscais do mesmo Tesouro, assim como tôdas as repartições que disponham de tesourarias próprias, como os Ministérios Militares, o Departamento Federal de Compras, o Estado Maior Geral das Fôrças Armadas, a Imprensa Nacional, etc. . As demais repartições a que os créditos são concedidos apenas realizam as despesas, empenhando-as e liquidando-as. Para que sejam pagas, mister se faz que requisitem o pagamento à estação pagadora. que detêm os créditos.

Nos mandados, como determina a Lei, devem ser indicados por extenso a importância a pagar e o nome do credor. As ordens de pagamento a menores, interditos ou ausentes são expedidas em favor de seus representantes legais, cujos nomes delas também constarão por inteiro.

Nas ordens coletivas se indicará o número de credores a serem pagos, nomeados em relação, e, bem assim, a importância total do pagamento. São. 
mais comuns essas ordens coletivas no Departamento Federal de Compras, onde é volumoso o movimento de faturas de fornecimento de material (art. 13 do D.L. n. ${ }^{0}$ 7.584, de 25-5-45). Ali as faturas são encaminhadas à Delegação do Tribunal de Contas mediante relação protocolada, independentemente de qualquer outra formalidade, além da classificação da despesa e da ordem de pagamento assinada em cada uma delas. O intúito da lei foi facilitar - registro que, de modo diferente, seria moroso, por constituir cada fatura um processo à parte. Em caso de diligência ou denegação de registro, a fatura ou faturas erradas são retiradas da relação, enquanto as demais têm curso normal.

\section{VI}

Requisito de suma importância, sem o qual não poderá ser cumprida a ordem de pagamento é aquêle que exige haver sido a despesa imputada ao título orçamentário devido, ou computado em crédito adicional, prèviamente registrado, e deduzida dos saldos correspondentes, no ato do empenho.

Imputação a crédito impróprio é motivo bastante para denegação de registro pelo Tribunal de Contas. Em face do $\S 3 .^{\circ}$ do art. 77 da Constituição, a recusa de registro por falta de saldo do crédito ou por imputação a crédito impróprio terá caráter proibitivo. É veto absoluto. Não poderão, dêsse modo, tais despesas ser registradas sob reserva, após despacho do Presidente da República, como acontece se a denegação tiver outro fundamento. É que as despesas precisam obedecer rigorosamente à especialização orçamentária ou aos fins previstos nas leis que autorizam a abertura dos créditos adicionais.

Discriminados os créditos, por essa discriminação se orientam os ordenadores de pagamentos, fazendo com que as despesas caibam exatamente na dotação a que correspondam e comportem nos respectivos saldos. A obediência a êsse preceito é de conseqüência proveitosa, porquanto não só possibilita a mais perfeita fiscalização da execução orçamentária, como dá lugar à multiplicação de saldos ao fim do exercício, redundando em economia para os cofres públicos. Sua desobediência é crime previsto no art. 315 do Código Penal:

"Dar às verbas ou rendas públicas aplicação diversa da estabelecida em lei:

Pena - detenção, de um a três meses, ou multa, de um conto a dez contos de réis."

O texto se refere à lei orçamentária ou àquelas que autorizam ao Poder Executivo a abertura dos créditos suplementares, especiais e extraordinários.

"O que a lei penal protege, na espécie, é, antes do mais, o interêsse público, no sentido mais amplo possível. Com tal interêsse público, aliás, não pode ser consoante que o funcionário público não observe lei, e, não a cumprindo ou cumprindo-a mal, dê a verbas e, portanto, a rendas públicas (genèricamente) ou a rendas públicas empregáveis em despesas prèviamente especificadas em leis orçamentárias, destino diverso do que dali consta. 
De notar que, no crime do artigo 315 não importa dizer que o emprêgo irregular de verba ou renda foi "justo", pois justiça (aequitas) não pode aplicar-se contra texto expresso da lei, ainda que efetivamente injusto e iníquo. Outrossim, não importa demonstrar que o emprêgo irregular de verba ou renda. pública obedeceu a propósitos honestos e teve também fins honestos. A lei positiva por que se deve reger a ordem jurídica sòmente coincide com o princípio de moral, quando o legislador o encampa. Finalmente, não aproveita, ainda demonstrar que a aplicação irregular foi mais racional do que seria, se obedecida a lei. $\mathrm{O}$ argumento lógico, ainda quando realmente insuscetível de contestação, não é o que em todos os casos se contém na lei. Esta, apesar de dura, de absurda, de injusta, de imoral, deve ser cumprida por aquêles a que se dirige, salvo se houver impossibilidade insuperável decorrente da natureza das coisas." (Fernando Henrique M. DE Almeida - Dos Crimes contra a Administração Pública, pág. 43-44).

Entretanto é anseio quase geral dos administradores a redução das ementas crçamentárias a um mínimo, notadamente no que se refere a despesas com material, havendo até quem sonhe com dotações globais referentes apenas a material permanente e de consumo, a fim de que haja mais maleabilidade no jôgo dos recursos para a aquisição de artigos necessários ao serviço público. Com efeito, por não ser o orçamento feito à base da realidade e, além disso, fundar-se em propostas dois anos atrazadas, é comum que certas repartições não possam adquirir materiais de que tenham real necessidade, por falta de verba própria, embora dispondo de saldos em dotações de que pràticamente não precisam. Daí as infrações da Lei de Meios por imputações de despesas a créditos diferentes, mediante artifícios de especificação ou, o que é mais grave, por meio de faturas de que constem mercadorias diversas das adquiridas ou serviços estranhos aos efetivamente executados.

É, porém, impossível a quem faz o exame da ordem do pagamento, diante apenas dos documentos que the são apresentados, concluir pela imputação a crédito impróprio, se tais documentos não reproduzem a verdade.

\section{VII}

Exige-se também que a despesa seja processada à vista de documentos que a comprovem, respeitado o processo estabelecido por lei. $\mathrm{O}$ art. 256 do R.G.C.P. já determinava que a liquidação da despesa consistiria na verificação do direito adquirido pelo credor, sôbre a base de títulos e documentos comprobatórios do respectivo crédito, expedidos na conformidade daquele Regulamento e dos regulamentos especiais para os diversos serviçcs públicos. Comumente êsses documentos consistem na ordem de pagamento propriamente dita, na conta, devidamente selada e nas primeira e segunda vias do empenho, esta última anexada ao processo pela Secretaria do Tribunal de Contas ou por suas Delegações. Da fatura devem constar, no verso, não só a classificação orçamentária da despesa como o certificado do recebimento do material ou da prestação do serviço. Outros títulos porém serão exigiveis em casos especiais. 
Prèviamente os ordenadores das despesas enviarão ao Tribunal de Contas ou suas Delegações, para o necessário exame, os processos de licitação (concorrências ou coletas), que são guardados para nova apreciação no momento do registro da despesa, a qual deve concordar inteiramente com os resultados obtidos, ou seja, especificação do material ou do serviço, preço unitário, quantidade e consignatário. $O$ exame das ordens de pagamento pelo Corpo Instrutivo do Tribunal de Contas exige a comparação entre a fatura e as concorrências ou coletas, a fim de que fique apurado ter a despesa se cingido aos resultados aprovados na licitação.

\section{VIII}

Se dependerem de contratos, as despesas devem guardar conformidade com as respectivas cláusulas. Dependem de contrato prévio despesas com aquisição de material em quantia superior a $\mathrm{Cr} \$ 150.000,00$, para as diversas repartições e além de $\mathrm{Cr} \$ 500.000,00$, para o Departamento Federal de Compras (arts. 36 e 37 do Decreto-lei n. ${ }^{\circ} 2.206$, de 20-5-40); transportes por emprêsas não tarifadas; aquisição de imóveis; aluguéis de casas; obras e serviços, ou outras despesas cujas características exijam estipulação de condições. Tais contratos são obrigatòriamente registrados pelo 'Tribunal de Contas que, ao examinar a ordem de pagamento, verificará se a despesa mantém perfeita conformidade com suas cláusulas.

Às Delegações não compete o registro de contratos, face a inteligência do ítem III do art. 77 da Constituição vigente. Cabe-lhes encaminhá-los, devidamente instruídos, à Côrte de Contas. Anteriormente à Constituição de 1946 competia-lhes o registro de contratos que importassem em despesa limitada, atribuição esta cassada no presente regime constitucional.

\section{IX}

Finalmente, se as despesas forem sujeitas ao registro prévio, não poderão ser cumpridas as ordens de pagamento respectivas se aquelas não houverem sido registradas pelo Tribunal de Contas ou por suas Delegações nos Estados, no Departamento Federal de Compras e na Imprensa Nacional. E' o que aliás proibe taxativamente o art. 279 do R.G.C.P.: "Sob responsabilidade estrita dos pagadores, nenhuma ordem de pagamento será cumprida sem haver sido prèviamente registrada pelo Tribunal de Contas ou por suas Delegações." $\mathrm{E}$ estabelece êste mesmo artigo que, caso os pagadores efetuem qualquer pagamento sem o preenchimento da exigência do registro prévio pelo Tribunal de Contas, serão as importâncias pagas levadas à conta de alcance dos mesmos pagadores.

O registro é a consequiência do julgamento da legalidade da despesa, não obstante o Tribunal se detenha também nos vários aspectos do dispêndio, inclusive na correição aritmética. 
A despesa pública subordina-se a um severo regime de legalidade, tendo em vista sua natureza política. Há de conformar-se, em primeiro lugar, dentro da autorização legislativa, não podendo ser efetuada acima dêsse limite, sob pena de responsabilidade funcional (Constituição, art. 89-VI e VII) declarada na Lei n. ${ }^{\circ} 1.079$, de 10 de abril de 1950 , que define os delitos em que podem incorrer o Presidente da República, os Ministros de Estado e os Governadores.

Há, quanto a despesas além dos créditcs autorizados, a exceção admitida no art. 46 do Código de Contabilidade, hoje considerada inconstitucional por recentes e sucessivas decisões do Tribunal de Contas, face o disposto no $\S 3 .^{\circ}$ do art. 77 da Constituição.

A legalidade da despesa, porém, verificada pelo Tribunal de Ccntas, abrange não só o aspecto orçamentário como todo o complexo de leis e regulamentos que a regulam, principalmente o Código e o Regulamento Geral de Contabilidade, nas partes que ainda não foram revogadas. 